\title{
FLORAL VOLATILES PLAY A KEY ROLE IN SPECIALIZED ANT POLLINATION
}

\section{CLARA DE VEGA ${ }^{1 *}$, CARLOS M. HERRERA ${ }^{1}$, AND STEFAN DÖTTERL ${ }^{2,3}$}

${ }^{1}$ Estación Biológica de Doñana, Consejo Superior de Investigaciones Científicas (CSIC), Avenida de Américo Vespucio s/n, 41092 Sevilla, Spain

${ }^{2}$ University of Bayreuth, Department of Plant Systematics, 95440 Bayreuth, Germany

${ }^{3}$ Present address: University of Salzburg, Organismic Biology, Hellbrunnerstr. 34, 5020

Salzburg, Austria

Running title —Floral scent and ant pollination

* For correspondence. E-mail cvega@ebd.csic.es

Tel: +34 954466700

Fax: + 34954621125 


\section{ABSTRACT}

Chemical signals emitted by plants are crucial to understanding the ecology and evolution of plant-animal interactions. Scent is an important component of floral phenotype and represents a decisive communication channel between plants and floral visitors. Floral

5 volatiles promote attraction of mutualistic pollinators and, in some cases, serve to prevent flower visitation by antagonists such as ants. Despite ant visits to flowers have been suggested to be detrimental to plant fitness, in recent years there has been a growing recognition of the positive role of ants in pollination. Nevertheless, the question of whether floral volatiles mediate mutualisms between ants and ant-pollinated plants still remains largely unexplored. Here we review the documented cases of ant pollination and investigate the chemical composition of the floral scent in the ant-pollinated plant Cytinus hypocistis. By using chemical-electrophysiological analyses and field behavioural assays, we examine the importance of olfactory cues for ants, identify compounds that stimulate antennal responses, and evaluate whether these compounds elicit behavioural responses. Our findings reveal that floral scent plays a crucial role in this mutualistic ant-flower interaction, and that only ant species that provide pollination services and not others occurring in the habitat are efficiently attracted by floral volatiles. 4-oxoisophorone, $(E)$-cinnamaldehyde, and (E)-cinnamyl alcohol were the most abundant compounds in Cytinus flowers, and ant antennae responded to all of them. Four ant pollinator species were significantly attracted to volatiles emitted by Cytinus inflorescences as well as to synthetic mixtures and single antennal-active compounds. The small amount of available data so far suggests that there is broad interspecific variation in floral scent composition among ant-pollinated plants, which could reflect differential responses and olfactory preferences among different ant species. Many exciting discoveries will be made as we enter into further research on chemical communication between ants and plants. 
Keywords: ant-plant mutualism; Cytinus hypocistis; floral scent; floral signal; GC-EAD (gas chromatography coupled to electroantennographic detection); plant-pollinator interactions 


\section{INTRODUCTION}

Associations between ants and plants have a long evolutionary history, possibly dating back to the Cretaceous, and exemplify a complex continuum from mutualism to antagonism (Rico-Gray and Oliveira, 2007). They can affect the structure and functioning of terrestrial

5 ecosystems and play a significant role in ecologically different habitats from tropical forests to temperate and alpine environments (Beattie, 1985; Rico-Gray and Oliveira, 2007). Antplant mutualistic interactions are more common than antagonistic ones, with seed dispersal and plant protection from herbivores being by far the best studied ant-plant mutualisms (Culver and Beattie, 1978; Heil and Mckey, 2003; Ness et al., 2004; Bronstein et al., 2006). Interactions between ants and flowers have traditionally been interpreted as antagonistic, but the outcome of that association can shift from negative to positive depending on the species involved and community context (Rico-Gray and Oliveira, 2007).

Ant visits to flowers have been generally suggested to be detrimental to plant fitness because ants consume floral nectar, may deter other flower visitors, and damage floral parts (Galen, 1983; Ramsey, 1995; Junker et al., 2007). In accordance with this interpretation, a variety of physico-chemical flower characteristics have been proposed as mechanisms for deterring ant visits (Guerrant and Fiedler, 1981; Junker and Blüthgen, 2008; Willmer et al., 2009; Junker et al., 2011a). The controversial question of whether ants have a beneficial or harmful effect on flowers also has to do with pollination. Ant workers have long been regarded as poor agents of cross-pollination because of their small size, lack of wings, and frequent grooming (but see Peakall and Beattie, 1991; Gómez and Zamora, 1992). Further, the ‘antibiotic hypothesis' provides an additional explanation as to why ants can be considered ineffective pollinators (Beattie et al., 1984; Peakall et al., 1991): the cuticular surface and metapleural glands of some ants produce compounds with antibiotic properties against bacterial and fungal attack, and these secretions may reduce pollen viability (Beattie et 
al., 1984, 1985; Hull and Beattie, 1988; Dutton and Frederickson, 2012; but see Peakall and Beattie, 1989; Peakall, 1994; Gómez and Zamora, 1992). Nevertheless, recent years have seen a growing recognition of the role of ants in effective pollination (Appendix 1), which demands a re-evaluation of earlier generalizations about the negative role of ants for flowers.

5 Pollination by ants has been reported so far for 18 monocot and dicot families and about 36 plant species, with 57 species from 5 subfamilies of ants described as pollinators (see Appendix 1 for details). These figures keep increasing as more information accumulates. Species of herbs, treelets, trees, shrubs, epiphytic, saprophytic and parasitic plants worldwide have been described to be ant-pollinated. Some of them live in habitats where ant frequency is high, and show features included in the "ant-pollination syndrome": short plants, and sessile and small flowers with nectar as the main reward (Hickman, 1974). In other cases, a correspondence between flower traits and ant pollination is not evident, but ants have nevertheless been proved to be effective pollinators (Peakall et al., 1987; Peakall, 1994; Ramsey, 1995; Sugiura et al., 2006).

Chemical communication between ants and plants is crucial for the establishment and avoidance of interactions, and plant volatile organic compounds (VOCs) are key elements in these processes. Vegetative volatiles released by myrmecophytic plants are decisive in attracting their obligate ant symbionts that help protect plants against herbivores (Agrawal, 1998; Brouat et al., 2000; Edwards et al., 2006; Inui and Itioka, 2007), and volatiles from seeds are crucial for the establishment of ant-gardens in obligate mutualisms between ants and epiphytes (Youngsteadt et al., 2008). In line with the prevailing detrimental role attributed to ants when they interact with flowers, floral volatiles have been shown to act as repellent allomones (Willmer and Stone, 1997; Junker and Blüthgen, 2008; Willmer et al., 2009; Junker et al., 2011b). Nevertheless, whether volatiles play some role in mutualistic ant-flower 
interactions, functioning as synomones that promote effective pollination, still remains largely unexplored (but see Schiestl and Glaser, 2012).

Floral scent is an important component of floral phenotype and represents a decisive communication channel between plants and animals. It facilitates attraction of pollinators

5 (Raguso, 2008) and promotes pollinator specificity by the intensity of the signal, the presence of unique VOCs, and exclusive multicomponent blends of ubiquitous compounds (Ayasse, 2006; Dobson, 2006; Raguso, 2008; Schiestl, 2010; Schiestl and Dötterl, 2012; FarréArmengol et al., 2013). The specificity of floral VOCs in attracting specific guilds of pollinators including moths, flies, bees, wasps, beetles, bats, or even rodents has been previously studied (Dobson, 2006; Knudsen et al., 2006; Raguso, 2008; Peakall et al., 2010; Johnson et al., 2011; Maia et al., 2012), but the chemical composition and function of the floral scent of species pollinated by ants remains virtually unexplored. Since chemical signals are essential sources of information to ants (Hölldobler, 1999; Lenoir et al., 2001; Martin et al., 2008; Heil et al., 2010), we hypothesize that plants should use floral scent to promote attraction of mutualistic ants when plants benefit from their pollination services.

By using the ant-pollinated plant Cytinus hypocistis (L.) L. (Cytinaceae) as model system, we explore here the hypothesis that floral scent also mediates mutualisms between ants and ant-pollinated plants. Cytinus-ant pollination provides an excellent system for testing this hypothesis because Cytinus flowers emit a weak sweetish scent (to the human nose) and ants have proved to be their effective pollinators, accounting for $97 \%$ of total floral visits and yielding a fruit set $~ 80 \%$ (de Vega et al., 2009). We report the chemical composition of Cytinus floral scent from different races and localities, and use chemical-electrophysiological analyses and field behavioural assays to examine experimentally the function of compounds found in floral scent. We identify compounds that stimulate antennal responses in ants and evaluate whether single compounds and synthetic blends elicit behavioural responses. Our 
findings reveal that an ant-pollinated plant can attract its ant pollinators by floral scent, and further highlight the need of reassessing the ecological significance and evolution of antflower interactions.

\section{MATERIAL AND METHODS}

\section{$5 \quad$ Study species}

Cytinus hypocistis is a root holoparasite that grows exclusively on Cistaceae host plants (de Vega et al., 2007, 2010). The inflorescences of this monoecious, self-compatible species are visible only in the blooming period (March-May), when bursting through the host root tissues (Fig. 1 A, B). The inflorescence is a simple short spike with $5.6 \pm 0.1$ (mean \pm s.e.) basal female flowers (range 1-14) and $6.2 \pm 0.1$ distal male flowers (range 1-17). Female and male flowers produce similar amounts of nectar, with a daily production of $\sim 1.5 \mu$ of sucrose-rich nectar (de Vega, 2007; de Vega and Herrera, 2012, 2013). Ants are the main pollinators, and exclusion experiments demonstrate that while foraging for nectar, ants efficiently pollinate flowers (de Vega et al., 2009). Among the most abundant daytime ant species visiting Cytinus flowers are Aphaenogaster senilis (Mayr 1853), Crematogaster auberti (Emery 1869) (Fig. 1C), C. scutellaris (Olivier 1792), Pheidole pallidula (Nylander 1849), Plagiolepis pygmaea (Latreille 1798) and Tetramorium semilaeve (André, 1883). During the night, Camponotus pilicornis (Roger, 1859) visits flowers (for further details see de Vega et al., 2009). Flying visitors are scarce; their contribution to seed set is generally negligible, and they only forage on Cytinus inflorescences lacking ants.

Cytinus shows a remarkable specialization at the host level, and forms distinct genetic races which are associated with different host plant species (de Vega et al., 2008). We studied Cytinus populations of two genetic races growing on two different hosts: Cistus albidus L. and C. salviifolious L. Cytinus with yellow flowers parasitized white-flowered Cistus 
salviifolious while Cytinus with white pinkish flowers parasitized pink-flowered Cistus albidus (Fig. 1A,B). For convenience, the material used in this study will be referred to hereafter as CytinusY (yellow-flowered individuals, Fig. 1A) and CytinusP (pink-flowered individuals, Fig. 1B).

\section{$5 \quad$ Study sites}

Two populations of CytinusY (CY1 and CY2) and two populations of CytinusP (CP1 and CP2) were studied in southern Spain. CytinusY populations were located in the

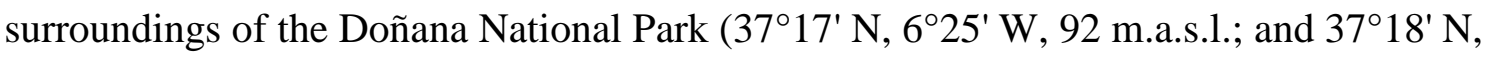
$6^{\circ} 25^{\prime}$ W, 100 m.a.s.l.) and CytinusP populations were located in the Sierra de Aracena y Picos de Aroche Natural Park (3752' N 640' W, 730 m.a.s.l.; and 3753' N, 6³9' W, 844 m.a.s.1.).

\section{Volatile collection}

To characterize the floral scent composition of Cytinus, volatiles were collected at the four Cytinus populations using the dynamic headspace methods as described by Dötterl et al. (2005a). Scent was collected from 4-5 inflorescences at each population. Samples were collected during the day (13 inflorescences from four populations) and night (five inflorescences from two populations) since Cytinus flowers received both diurnal and nocturnal visits from ants (de Vega et al., 2009). Female and male flowers were further analyzed independently to study differences in floral scent between the genders (4-11 flowers of each sex, 9-18 flowers in total per inflorescence). Flowers were removed from the inflorescence, given that they are sub-sessile, and are arranged in the inflorescence in such a way that floral scent of each gender could not be analysed independently unless flowers were cut (Fig 1A, B). To identify flower-specific scents we additionally collected volatiles from the inflorescence axis without flowers. Complete inflorescences were sampled in two of the populations to test for compounds induced by cutting. A comparison of complete 
inflorescence and flower scent samples revealed that floral scent was not influenced by removing the flowers from the inflorescence axis.

From each inflorescence we therefore collected three sample groups, namely male flowers, female flowers and inflorescence axis. Overall we analyzed the scent from 18

5 inflorescences and 32 floral samples (17 and 15 groups of female and male samples, respectively; three male samples and one female sample were discarded due to technical problems) (Table 1). For scent collection, either flowers or the stem were enclosed for 20 min within a polyethylene oven bag $(10 \mathrm{~cm}$ x $10 \mathrm{~cm})$, after which the emitted and accumulated volatiles were trapped for 2 min in a filter containing a mixture of $1.5 \mathrm{mg}$ Tenax-TA (mesh 60-80; Supelco, Germany) and 1.5 mg Carbotrap B (mesh 20-40, Supelco, Germany). A battery-operated membrane pump (G12/01 EB, Rietschle Thomas, Puchheim, Germany) was used to generate a flow rate through the filter of $200 \mathrm{ml} \mathrm{min}^{-1}$.

To determine the amount of scent released from a paper wick used for bioassays (see below), $20 \mu \mathrm{l}$ of a 1:1:1 mixture of 4-Oxoisophorone, $(E)$-Cinnamaldehyde, and (E)-Cinnamyl alcohol $\left(0.5 \times 10^{-3}\right.$; diluted in paraffin; v/v) was added to a wick. Five minutes later the wick was enclosed in an oven bag as described before and scent was subsequently collected for two minutes (two replicates). All samples collected were kept frozen $\left(-20^{\circ} \mathrm{C}\right)$ until analysis.

\section{Chemical analyses}

For identification of trapped volatiles, headspace samples were analyzed on a Varian Saturn 2000 mass spectrometer coupled to a Varian 3800 gas chromatograph (GC) equipped with a 1079 injector (Varian Inc., Palo Alto, CA, USA), which had been fitted with the ChromatoProbe kit (Amirav and Dagan 1997, Dötterl et al., 2005a). Samples were directly inserted in the injector by means of the ChromatoProbe and analyzed by thermal desorption. For all samples, the injector split vent was opened and the injector heated to $40^{\circ} \mathrm{C}$ to flush any 
air from the system. The split vent was closed after $2 \mathrm{~min}$, and the injector was heated at a rate of $200^{\circ} \mathrm{C} / \mathrm{min}$ to $200^{\circ} \mathrm{C}$, then held at $200^{\circ} \mathrm{C}$ for $4.2 \mathrm{~min}$, after which the split vent was opened and the injector cooled down. Separations were achieved with a fused silica column ZB-5 (5\% phenyl polysiloxane; $60 \mathrm{~m}$ long, inner diameter $0.25 \mathrm{~mm}$, film thickness $0.25 \mu \mathrm{m}$,

5 Phenomenex). Electronic flow control was used to maintain a constant helium carrier gas flow of $1.0 \mathrm{~mL} \mathrm{~min}{ }^{-1}$. The GC oven temperature was held for $7 \mathrm{~min}$ at $40^{\circ} \mathrm{C}$, then increased by $6^{\circ} \mathrm{C}$ per min to $250^{\circ} \mathrm{C}$ and held for $1 \mathrm{~min}$. The interface to the mass spectrometer worked at $260^{\circ} \mathrm{C}$ and the ion trap at $175^{\circ} \mathrm{C}$. Mass spectra were taken at $70 \mathrm{eV}$ (in EI mode) with a scanning speed of 1 scan sec $^{-1}$ from m/z 30 to 350. The GC-MS data were processed using the Saturn Software package 5.2.1.

Identification of compounds was carried out using the NIST 08, Wiley 7, and Adams 2007 mass spectral data bases, or the data base provided in MassFinder 3, and confirmed by comparison of retention times with published data (Adams, 2007). Structure assignment of individual components was confirmed by comparison of both mass spectra and GC retention times with those of authentic standards. To determine the total amount of scent trapped, known amounts of monoterpenes, aliphatics, and aromatics were injected into the GC-MS system. Mean peak areas of these compounds were used to determine the total amount of scent (for more details see Dötterl et al., 2005a). By applying this method, the mean values (two replicates) for the amount of scent trapped from the wicks used for bioassays (1:1:1 diluted in paraffin, at overall $0.5 \times 10^{-3}$; see below) were determined to be $2721 \mathrm{ng}$ per hour of 4-oxoisophorone (extrapolated based on the 2 min collections), 229 ng of (E)Cinnamaldehyde, and 2 ng of (E)-Cinnamyl alcohol. These differences in trapping/emission rates have to do with methodological/technical issues, such as the solubility in paraffin and the vapor pressure of the compounds. Considering the number of flowers (see Study species) and amount of scent trapped per inflorescence (see Statistical analyses), the amounts trapped 
from the wicks closely resemble a single inflorescence [(E)-cinnamaldehyde, $(E)$-cinnamyl alcohol] or a few inflorescences (4-oxoisophorone).

\section{Coupled Gas Chromatography-Electroantennographic Detection (GC-EAD)}

We used GC-EAD to test whether antennae of pollinating ants respond to main

5 compounds of Cytinus floral scent. GC-EAD analyses were performed on a Vega 6000 Series 2 GC (Carlo Erba, Rodano, Italy) equipped with a flame ionization detector (FID), and an EAD setup (heated transfer line, 2-channel USB acquisition controller) provided by Syntech (Hilversum, Netherlands) (for more details, see Dötterl et. al., 2005b). 4-Oxoisophorone, (E)Cinnamaldehyde and (E)-Cinnamyl alcohol (all Sigma-Aldrich; at least 98\%) were used for analyses (1000 fold diluted in Acetone; v/v) and antennae of Aphaenogaster senilis (four antennae from three individuals), Crematogaster auberti (three antennae from three individuals), Pheidole pallidula (five antennae from four individuals), and Plagiolepis pygmaea (three antennae from three individuals) were available for measurements. Separations were achieved in splitless mode ( $1 \mathrm{~min})$ on a ZB-5 capillary column (30 m × 0.32 $\mathrm{mm}, 0.25 \mu \mathrm{m}$ film thickness, Phenomenex, Torrance, CA, USA), starting at $60^{\circ} \mathrm{C}$, then programmed at a rate of $10^{\circ} \mathrm{C} / \mathrm{min}$ to $200^{\circ} \mathrm{C}$ and held there for $5 \mathrm{~min}$. For the EAD, both ends of an excised antenna were inserted in glass micropipette electrodes filled with insect ringer solution (8.0 g/l NaCl, $0.4 \mathrm{~g} / \mathrm{l} \mathrm{KCl,} 4 \mathrm{~g} / \mathrm{l} \mathrm{CaCl}_{2}$ ) and connected to silver electrodes. The measurements turned out to be quite noisy (see Results), which might have to do with the structure and morphology of the antennae (e.g. strongly chitinized, tiny) resulting in high electrical resistance. This background noise strongly hampered the identification of clear responses when using natural scent samples, most likely because of the quite diluted samples available. We therefore performed measurements with authentic standards to test if ants 
respond to the main floral compounds. Only after finding that main compounds elicit antennal responses did we use them for behavioral assays.

\section{Behavioral responses of ants to floral volatiles}

To test the response of insects to Cytinus floral scent, a field-based choice experiment

5 was conducted. The behavioral effects elicited by naturally emitted volatiles from inflorescences were examined by excluding responses that require visual or tactile cues. Each experimental arena (two-choice test) consisted of two pits dug in the soil ( $8 \mathrm{~cm}$ diameter $\times 10$ cm depth) $10 \mathrm{~cm}$ apart. One pit was left empty (control) and in the other a Cytinus inflorescence was introduced. Both pits were covered with opaque mesh permeable to odor $(12 \times 12 \mathrm{~cm})$ with the edges buried in the soil, preventing visual and tactile cues of inflorescences. This experiment was replicated 27 times in one CytinusY population (CY1) over three different days. To ensure that an ant's choice was not influenced by previous visits to the flowers before trials, only recently opened fresh inflorescences not yet visited by ants were used. Observers were situated $1.5 \mathrm{~m}$ from each focal trial, and ants were recorded during 5-min long watching periods (hereafter 'censuses') throughout daytime when possible (09:0020:00; one census per hour and trial). A total of 810 min of censuses were conducted (162 censuses in total). We recorded ant identity, number of visits and activity (pass or touch and antennae movement). An ant was considered to have made a choice if it stayed at least 10 sec. over the mesh. We performed the behavioural experiments in flowering populations, so that ants responding to the natural and synthetic scents could have visited Cytinus before and could have been scent-experienced. However, we cannot rule out that at least some of the responding ants were Cytinus-naïve and the response to the scents was innate.

We additionally recorded the presence of all ant taxa that were active in the study populations but did not attend Cytinus natural inflorescences or the biotest. 


\section{Behavioral responses of ants to synthetic compounds}

In a second field-based two-choice experiment, the three EAD-active and main synthetic compounds identical to those present in Cytinus flowers [(E)-cinnamyl alcohol, $(E)$ cinnamaldehyde, and 4-oxoisophorone, diluted in paraffin at $0.5 \times 10^{-2}$; see Results] and a

5 mixture of them (1:1:1 diluted in paraffin, at overall $0.5 \times 10^{-3}$; Uvasol, Merck, Germany) were offered in the field to ants. The experiment was designed to address whether volatile compounds trigger not only electrophysiological responses (see Results) but also behavioural responses in pollinators. Given that the flowers of CytinusP and CytinusY showed similar scent compounds (see Results), this experiment exploring the attractiveness of synthetic compounds was conducted only in one CytinusY population (CY2) during the flowering period.

Each trial consisted of placing two $12 \times 5 \mathrm{~mm}$ paper wicks (Whatman17MM) $7 \mathrm{~cm}$ apart on $12 \times 4 \mathrm{~cm}$ paperboard sheets on the ground. Twenty microliters of each individual compound or their mixture were pipetted onto one wick, and paired with a control wick to which $20 \mu \mathrm{L}$ of paraffin was added. The first census was done 5 min after adding the compounds. Experimental trials were randomly placed at soil level in a natural Cytinus population as to provide access to any foraging insect species. We replicated 50 times the 1:1:1 mixture and $(E)$-cinnamyl alcohol, and 25 times 4-oxoisophorone and $(E)-$ cinnamaldehyde.

Volatile compounds were diluted in paraffin for obtaining concentrations similar to those found in plant scent. Paraffin oil is a mixture of n-alkanes frequently used as a release agent of the semiochemical to examine the attractiveness of the compounds to several insect groups (Dötterl et al., 2006; Valterová et al., 2007; Verheggen et al., 2008; Steenhuisen et al., 2013) including ants (Junker and Blüthgen, 2008; Junker et al., 2011b). Some particular cuticular hydrocarbons have important communicative functions in ants (Lucas et al., 2005; 
Martin et al., 2008). However, n-alkanes are abundant in plant and insect waxes, being found in almost every insect species (Blomquist and Bagnères, 2010). Due the universal occurrence of n-alkanes, this type of hydrocarbon is assumed not to be relevant in ant communication, and indeed experimental data proved that ants do not respond to n-alkanes (see reviews by

5 Martin and Drijfhout, 2009; van Wilgenburg et al., 2011). It is therefore unlikely that paraffin influenced the outcome of the behavioural assays.

Observers were situated $1.5 \mathrm{~m}$ from focal trial, and ant behavior and number of visits were observed for 1-min periods in 910 censuses. Censuses began at 9 AM and continued up to 4 PM during three days accounting for a total of 910 min of field observations. In the course of the experiment, we additionally recorded the presence of all ant species that were active in the area occupied by the Cytinus population, irrespective of their activity or their attraction to Cytinus plants.

\section{Statistical analyses}

Regardless of population, inflorescence and flower sex, the amount of scent trapped was quite variable (overall 0.2-31.4 ng on a per hour and flower basis). We therefore focused our analysis on relative (percentage of the total peak area) rather than absolute amounts of scent components. Semiquantitative similarities in floral scent patterns among samples were calculated with the Bray-Curtis similarity index in the statistical software PRIMER 6.1.11 (Clarke and Gorley, 2006). To test for scent differences between female and male flowers, we calculated a PERMANOVA (10,000 permutations, in PRIMER 6.1.11) based on the BrayCurtis similarity matrix. PERMANOVA is a technique for testing the simultaneous response of one or more variables to one or more factors in an ANOVA experimental design on the basis of a (dis)similarity (distance) matrix with permutation methods (Anderson et al., 2008). The analysis employed a two-way crossed design with sex as the fixed factor and 
inflorescence as the random factor. This analysis revealed that female and male flowers of a specific inflorescence emitted the same scent (see Results). We therefore calculated the mean relative amount of scent for each inflorescence, computed semiquantitative similarities (BrayCurtis similarity index) in scent patterns among inflorescences, and used these data for all 5 further analyses.

Nonmetric multidimensional scaling (NMDS) was performed (based on the Bray-Curtis similarity index) to depict variation in floral scent among the inflorescences (Clarke and Gorley, 2006). Nocturnal and diurnal samples occupied similar locations in a 2-dimensional odour space, and similarity within nocturnal and diurnal samples was not higher than similarity between nocturnal and diurnal samples (PERMANOVA: Pseudo- $F_{1,17}=0.65, P=$ 0.62). A PERMANOVA analysis to test differences in scent among populations $(10,000$ permutations; fixed factor: population) was then applied to pooled diurnal and nocturnal data.

All analyses regarding preferences of ants in the field for paired-scent stimuli were conducted using SAS 9.2 (SAS Institute Inc., Cary, NC, USA). Differences in ant choice for natural inflorescence scent or control, and deviations of ant choice from a neutral preference between wicks with synthetic compounds and control were assessed by fitting generalized linear models (procedure GENMOD of SAS) with the binomial error distribution and logit link function. Differences in the number of ants attending to flower scent stimuli and control treatment, and differences in the number of ant visits between synthetic compounds and control, were compared using procedure GENMOD with the Poisson distribution and log as the link function. A scale parameter, estimated by the square root of the deviance of the model divided by its degrees of freedom, was used to correct for overdispersion in the model. Tukey post hoc tests were used to determine which treatments differed significantly.

\section{RESULTS}




\section{Floral scent}

Regardless of population and daytime, compounds emitted by Cytinus flowers consisted of aromatics (eight compounds) and irregular terpenes (three compounds) (Table 1). Inflorescence axes did not emit these volatiles. Within inflorescences, emissions from female

5 and male flowers conformed to the same scent profile (PERMANOVA: Pseudo- $\mathrm{F}_{1,31}=0.58$, $P=0.62$ ), hence further analyses focused exclusively on the inflorescence level. Depending on the inflorescence sampled, $(E)$-cinnamaldehyde, $(E)$-cinnamyl alcohol, 4-oxoisophorone, or 4-oxoisophorone epoxide were the most abundant scent compounds (Table 1). Only rarely (1 of the 18 sampled inflorescences) did benzaldehyde dominate the scent profile. Many samples contained considerable amounts of $(E)$-cinnamaldehyde along with high amounts of one or two of the other compounds (Table 1, Fig. 2). The PERMANOVA analysis suggest that semiquantitative variation in scent within populations could be considered comparable to variation among populations (Pseudo- $F_{3,17}=1.56, P=0.14$ ). One would be tempted to suggest that these results point to scent homogeneity across Cytinus races and populations. However, because of the small sample size, these inferences should be interpreted with caution.

\section{Electroantennogram (EAG) responses}

Results from measurements with ant antennae were very noisy, probably because of strongly chitinized antennae resulting in high electrical resistance (see Material and Methods). However, three runs resulted in responses to compounds clearly differentiated from the noise and demonstrated that ants can perceive the main compounds occurring in Cytinus floral scent (Fig. 3). Two antennae from two different individuals of $A$. senilis responded to (E)cinnamaldehyde, (E)-cinnamyl alcohol and 4-oxoisophorone (Fig. 3), and one antenna of $P$. pallidula responded to (E)-cinnamyl alcohol. 


\section{Ant responses to floral volatiles}

Six different ant species (Aphaenogaster senilis, Crematogaster auberti, Crematogaster scutellaris, Pheidole pallidula, Plagiolepis pygmaea, and Tetramorium semilaeve) were recorded in the experimental trials, accounting for 154 visits. These ant species were also

5 observed pollinating Cytinus flowers. Ants visited experimental pits throughout the day with the most visits coming in the afternoon. The number of individuals attracted to Cytinuscontaining pits was always higher than the number attracted to controls (Fig. 4A). They made overall 86\% of visits to pits with hidden inflorescences and 14\% to control ones (overall 21 visits to control vs. 133 visits to Cytinus), showing a strong preference for pits containing Cytinus olfactory cues (hidden inflorescences; Wald $\chi^{2}=36.6, \mathrm{df}=1, P<0.0001$ ). In addition, Cytinus-containing pits were visited in each census by a significantly higher number of ant individuals than control pits $\left(\chi^{2}=47.9, \mathrm{df}=1, P<0.0001\right)$. All pairs of experimental pits were visited.

Aphaenogaster senilis $\left(\chi^{2}=10.3, \mathrm{df}=1, P=0.001\right)$, C. auberti $\left(\chi^{2}=24.1, \mathrm{df}=1, P<\right.$ 0.0001), $P$. pallidula $\left(\chi^{2}=21.6, \mathrm{df}=1, P<0.0001\right)$, and $P$. pygmaea $\left(\chi^{2}=32.2, \mathrm{df}=1, P<\right.$ 0.0001) were significantly more attracted to volatiles emitted by Cytinus inflorescences than to controls (Fig. 4B, Fig. 1S). Crematogaster scutellaris and T. semilaeve showed no statistically significant preference.

Ant behavior differed drastically depending on the choice. When approaching pits containing inflorescences ( $\mathrm{N}=131$ observations), ants bit the mesh, trying to penetrate it, $68 \%$ of the time; ants walked over the mesh, constantly examining it and continually moving their antennae, $31.2 \%$ of the time; and only $0.8 \%$ of the time did they show no clear response to scent stimulation. In contrast, when visiting control pits, ants never tried to bite the mesh, and displayed a passive behavior, wandering over the mesh without any obvious purpose. 
In the study population other ant species were observed, including Formica subrufa, Messor spp., and Goniomma sp, but none of them foraged on open Cytinus plants or attended experimental trials.

\section{Ant responses to synthetic compounds}

Four ant species, A. senilis (Fig. 1D), C. auberti, P. pygmaea, and T. semilaeve, were observed in the experimental trials, accounting overall for 87 insect visits. The species $A$. senilis was observed most often (71.8\% of visits) followed by C. auberti (11.8\%), P. pygmaea and T. semilaeve (8.2\%).

Some of the floral volatiles that elicited electrophysiological responses were behaviourally active to ant species in the field bioassays, and responses to most compounds were significantly greater than those to paraffin oil controls. Ants were rapidly attracted and excited in response to single synthetic compounds and their mixture. Ants moved their antennae quickly and remained for several seconds touching the wick, a response comparable to that observed with natural Cytinus scents. A significant preference was observed for wicks containing the mixture of synthetic compounds (Wald $\left.\chi^{2}=10.5, \mathrm{df}=1, P=0.001\right),(E)$ cinnamyl alcohol $\left(\chi^{2}=9.3, \mathrm{df}=1, P=0.002\right)$ and $(E)$-cinnamaldehyde $\left(\chi^{2}=16.6, \mathrm{df}=1, P<\right.$ 0.0001) over control wicks with paraffin only (Fig. 5). Posthoc tests showed no differences of ant preferences between $(E)$-cinnamaldehyde, $(E)$-cinnamyl alcohol and the mixture of the compounds (Fig. 5). The number of ants attending wicks containing the mixture of synthetic compounds $\left(\chi^{2}=52.6, \mathrm{df}=1, P<0.0001\right),(E)$-cinnamyl alcohol $\left(\chi^{2}=66.0, \mathrm{df}=1, P<0.0001\right)$ and $(E)$-cinnamaldehyde $\left(\chi^{2}=79.5, \mathrm{df}=1, P<0.0001\right)$ was higher than the number in control wicks (Fig. 2S). No preference for 4-oxoisophorone was observed (Fig. 5).

\section{DISCUSSION}


Our study has provided compelling evidence that ants are strongly attracted by Cytinus floral scent. Chemical cues alone were sufficient to elicit conspicuous positive responses in several ant species that effectively pollinate Cytinus flowers. Ants have been traditionally considered nectar thieves, and even some flowers have been shown to emit volatiles

5 (allomones) repellent for ants (see references in the Introduction). However, we have shown that when plants benefit from ant visitation, floral volatiles can function as synomones with an important role in ant attraction. Since ants that function as efficient pollinators are attracted by Cytinus floral scent, floral volatiles clearly provide an advantage to the plant and may help to maintain a mutualistic relationship with ants, as discussed below.

\section{Communication signals between Cytinus and ant pollinators}

Any cue improving the net benefit for each partner in a plant-animal mutualism may evolve into a communication signal (Blatrix and Mayer, 2010). Visual and olfactory signals that help guide insects to the flowers and favour pollination are consequently expected to play an important role in the ecology and evolutionary diversification of plant-pollinator interactions (Raguso, 2001; Fenster et al., 2004; Peakall et al., 2010; Schiestl, 2010; Schäffler et al., 2012). Cytinus has brightly-coloured flowers that may have evolved to increase their visual attraction to pollinators. However, the inflorescences appear at ground level under the canopy of their host plant, and sometimes are even found hidden in leaf litter. This could reduce their visual conspicuousness and hence could limit the importance of visual cues for insect attractiveness. Since Cytinus depends on pollinators to set seed (de Vega et al., 2009), we suggest that the evolution of olfactory cues may have played an important role in the attraction of ground-dwelling insect pollinators.

Male and female flowers of Cytinus, during both the day and night, produced a sweet scent (to the human nose) with (E)-cinnamyl alcohol, (E)-cinamaldehyde and 4- 
oxoisophorone predominating in the volatile profile. These compounds occur in floral scents of a number of plant families (reviewed by Knudsen et al., 2006). Unlike what usually happens in other species, the scent of Cytinus is composed mainly of the above-metioned volatiles. Variation in scent (relative amount of compounds) within and among populations

5 seems to be high, as previously observed in other plant species (e.g., Dötterl et al., 2005a; Ibanez et al., 2010). Most importantly, the presence of the main compounds was constant across all Cytinus populations and races, a finding that suggests they are important signalling molecules. Supporting this idea, our results have shown that volatiles released only by the flowers, and particularly $(E)$-cinnamyl alcohol and $(E)$-cinamaldehyde, play an important role in the attraction of pollinators to Cytinus flowers. Four species of ants responded to chemical stimuli from Cytinus, all of which were previously observed pollinating Cytinus flowers (de Vega et al., 2009).

Ants generally use volatiles as cues for orientation to food sources and host plants (Edwards et al., 2006; Youngsteadt et al., 2008; Blatrix and Mayer, 2010), but our results show that Cytinus floral volatiles were not equally relevant for all local ant species. The conspicuous lack of response to Cytinus floral scent by granivorous ants that forage in the same populations suggest that floral volatiles are signals only for those ants that maintain a mutualistic interaction with Cytinus. Our results suggest that Cytinus encourages visitation and fidelity of ants that have proved to effectively pollinate flowers. By providing floral rewards and releasing attractive volatile compounds, Cytinus flowers obtain in return the byproduct benefit of pollination.

\section{Lack of responses in other pollinator guilds and consideration of the context}

Some of the volatile compounds released by Cytinus flowers are known to attract bees and are suggested to attract butterfly pollinators (Andersson et al., 2002; Andersson, 2003; 
Andrews et al., 2007), and are used by insects as signals in other contexts (e.g. pheromones, host finding cue of herbivores; Schulz et al., 1988; Metcalf and Lapmann, 1989; Metcalf et al., 1995). However, neither bees nor butterflies, the prevailing pollinators of many plants coexisting with Cytinus, were detected in the experimental trials or in exposed inflorescences.

5 This absence was confirmed by pollinator observations in more than 50 populations during ten years (de Vega, 2007; de Vega, unpublished results). Floral scent may not function alone and other sensory cues may be involved in pollinator attraction, including location, floral morphology, color and rewards. Cytinus is potentially an attractive plant species that has bright-coloured flowers that offer high quantities of pollen and sucrose-rich nectar, and it blooms in spring when many insects are present in the populations (de Vega et al., 2009). The absence of bees and butterflies visiting Cytinus was previously considered as a consequence of the continuous presence of ants that could be deterring flying pollinators, such as occurs in other species (Philpott et al., 2005; Ness, 2006). One is tempted to suggest that visual cues in Cytinus could have, at least in the studied populations, a minor importance, since inflorescences are at soil level and are frequently hidden under their host plants. This fact, together with the evident attraction of its floral volatiles to ants, may suggest that Cytinus floral traits are acting as signal rewards to this set of effective pollinating insects. Nevertheless, since Cytinus pollen has been found in honey samples in the Mediterranean area (Fernández et al., 1992; Yang et al., 2012), the potential attractive of Cytinus flowers for bees in other populations cannot be discarded.

\section{Cytinus vs. other ant-pollinated plants}

There is a scarcity of experimental evidence on the importance of floral volatiles in ant attraction, and our understanding of ant-flower systems is still in its infancy. To date, only the floral scent of an ant-pollinated orchid has been examined (Chamorchis alpine; Schiestl and 
Glaser, 2012). Volatiles emitted by two other species, where ants are less important pollinators in comparison to flying visitors (Fragaria virginiana: Ashman and King, 2005; Ashman et al., 2005; Euphorbia cyparissias: Schürch et al., 2000), have also been studied. The major components of the floral scent bouquet of the orchid C. alpine are linalool, $\alpha-$

5 terpineol, and eucalyptol (Schiestl and Glaser, 2012), all of them common terpenoids found in many flowering plants (Knudsen et al., 2006) and attractive for many pollinators (Dobson, 2006). Ants responded to a synthetic mixture containing all the compounds found in the scent (which included also $\beta$-phellandrene, $\beta$-caryophyllene), but it is unclear whether they responded to single compounds. Fragaria virginiana and E. cyparissias emitted floral scents made up of similarly widespread compounds, including also linalool, $\beta$-caryophyllene, and $\alpha$ terpineol. However, their scents were dominated by other compounds such as, e.g., $\alpha$-pinene and (E)- $\beta$-ocimene (Ashman et al., 2005; Kaiser, 2006). Interestingly, none of these plants emitted any of the cinnamic compounds and oxoisophorone that we found so abundant in Cytinus scent. Although the scanty evidence available renders any conclusions premature, there seems to be broad interspecific variation in the floral scent composition of ant-pollinated plants. This could in turn reflect differential responses and olfactory preferences by different ant species. Consistent with this interpretation is the observation that compounds described as repellent for some ants, such as linalool (Junker and Blüthgen, 2008), may elicit attractive responses in others and be important in ant-plant pollination mutualisms (Schiestl and Glaser, 2012). We suspect that in some cases the existence of specific floral volatiles that attract ants will be the evolutionary result of adaptation towards the olfactory preferences of the ant pollinators (see also Schiestl and Dötterl, 2012). Nevertheless in other cases ants may exploit compounds that were evolved primarily in order to attract other groups of pollinators. Potential differences of the importance of floral signals and specific volatiles between 'adapted' and 'casual’ ant-pollination systems offers a promising field for future research. 


\section{Signaling and pollination systems in Cytinaceae}

The role of floral scent in promoting the establishment of ant-plant mutualistic interactions revealed by this study supports the predicted importance of chemical signals for plant-animal interactions in the fascinating family Cytinaceae (de Vega, 2009). This family

5 only comprises two genera: Cytinus with 5-8 species in two centres of diversification (Mediterranean Region and South Africa-Madagascar) and Bdallophyton with three species in Central America (Mabberley, 1997; Alvarado-Cárdenas, 2009). It has been reported that aliphatic ketones attract small mammal pollinators to C. visseri in South Africa (Johnson et al., 2011), and that the sweet uncharacterized scent of subterranean Cytinus sp. attracts nonpollinating lemurs in Madagascar (Irwin et al., 2007), while a yeasty scent attracts carrion flies to Bdallophyton bambusarum in Mexico (García-Franco and Rico-Gray, 1997). Interestingly, bird- and ant-pollination have also been inferred for other South African Cytinus (Visser, 1981). The ecological and evolutionary mechanisms acting on plantpollinator signalling in Cytinaceae clearly deserve further studies. We suggest that in this family the importance of visual traits for attracting pollinators is heavily constrained by the fact that flowers occur at ground level and are often obscured by foliage, and that pollinators may therefore have shaped the evolution of floral scent. This provides an unrivalled opportunity for understanding the role of olfactory cues in the divergence of pollination systems.

\section{Acknowledgments}

We thank M. Dötterl for help during a field trip, Dr. R. G. Albaladejo for field assistance and several photographs, and the subject editor, three anonymous referees and Dr. R. Peakall for helpful comments on the manuscript. This work was supported by funds from Consejería de Innovación, Ciencia y Empresa, Junta de Andalucía (Proyecto de Excelencia P09-RNM-4517 
to CMH), Ministerio de Ciencia e Innovación (grant CGL2010-15964 to CMH) and Juan de

la Cierva Program to CdV.

\section{REFERENCES}

Adams, R.P., 2007. Identification of essential oil components by gas chromatography/mass spectrometry. Allured Publishing Corporation, Carol Stream, Illinois.

Agrawal, A.A., 1998. Leaf damage and associated cues induce aggressive ant recruitment in a neotropical ant-plant. Ecology 79, 2100-2112.

Alvarado-Cárdenas, L.O., 2009. Sistemática del género Bdallophytum (Cytinaceae). Acta Bot. Mex. 87, 1-21.

Amirav, A., Dagan, S., 1997. A direct sample introduction device for mass spectrometry studies and gas chromatography mass spectrometry analyses. Eur. Mass Spectrom. 3, $105-111$.

Anderson, M.J., Gorley, R.N., Clarke K.R., 2008. PERMANOVA+ for PRIMER, Guide to software and statistical methods. PRIMER-E, Plymouth, UK.

Andersson, S., 2003. Antennal responses to floral scents in the butterflies Inachis io, Aglais urticae (Nymphalidae), and Gonepteryx rhamni (Pieridae). Chemoecology 13, 13-20.

Andersson, S., Nilsson, L.A., Groth, I., Bergström, G., 2002. Floral scents in butterflypollinated plants: possible convergence in chemical composition. Bot. J. Linn. Soc. 140, $129-153$.

Andrews, E.S., Theis, N., Adler, L.S., 2007. Pollinator and herbivore attraction to Cucurbita floral volatiles. J. Chem. Ecol. 33, 1682-1691.

Ashman, T.L., King, E.A., 2005. Are flower-visiting ants mutualists or antagonists? A study in a gynodioecious wild strawberry. Am. J. Bot. 92, 891-895. 
Ashman, T.L., Bradburn, M., Cole, D.H., Blaney, B.H., Raguso, R.A., 2005. The scent of a male: the role of floral volatiles in pollination of a gender dimorphic plant. Ecology 86, 2099-2105.

Ayasse, M., 2006. Floral scent and pollinator attraction in sexually deceptive orchids. In, Dudareva, N., Pichersky, E. (Eds.) Biology of floral scent. Taylor \& Francis Group; Boca Raton, pp. 219-241.

Beattie, A.J., 1985. The evolutionary ecology of ant-plant mutualisms. Cambridge University Press, Cambridge.

Beattie, A.J., Turnbull, C., Knox, R.B., Williams E.G., 1984. Ant inhibition of pollen functions, a possible reason why ant pollination is rare. Am. J. Bot. 71, 421-426.

Beattie, A.J., Turnbull, C., Hough, T., Jobson, S., Knox, R. B., 1985. The vulnerability of pollen and fungal spores to ant secretions: evidence and some evolutionary implications. Am. J. Bot. 72, 606-614.

Blatrix, R., Mayer. V., 2010. Communication in ant-plant symbioses. In, Baluška, F., Ninkovic, V. (Eds.) Plant communication from an ecological perspective. Springer; Berlin Heidelberg, pp. 127-158.

Blomquist, G.J., Bagnères, A.G., 2010. Insect hydrocarbons: biology, biochemistry, and chemical ecology. Cambridge University Press; Cambridge.

Bronstein, J.L., Alarcón, R., Geber, M., 2006. The evolution of plant-insect mutualisms. New Phytol. 172, 412-428.

Brouat, C., McKey, D., Bessibre, J.M., Pascal, L., Hossaert-McKey, M., 2000. Leaf volatile compounds and the distribution of ant patrolling in an ant-plant protection mutualism, preliminary results on Leonardoxa (Fabaceae, Caesalpinioideae) and Petalomyrmex (Formicidae, Formicinae). Acta Oecol. 21, 349-57. 
Clarke, K.R., Gorley R.N., 2006 . Primer v6, User manual/tutorial. PRIMER-E, 1-91, Plymouth, UK.

Culver, D.C., Beattie, A.J., 1978. Myrmecochory in Viola, dynamics of seedant interactions in some West Virginia species. J. Ecol. 66, 53-72.

5 de Vega, C., 2007. Reproductive biology of Cytinus hypocistis (L.) L., host-parasite interactions. PhD Thesis, University of Seville, Spain.

de Vega, C., 2009. The importance of floral signals in the establishment of plant-ant mutualisms. Plant Sig. Behav. 4, 517-518.

de Vega, C., Ortiz, P.L., Arista, M., Talavera, S., 2007. The endophytic system of Mediterranean Cytinus (Cytinaceae) developing on five host Cistaceae species. Ann. Bot. 100, 1209-1217.

de Vega, C., Berjano, R., Arista, M., Ortiz, P.L., Talavera, S., Stuessy, T.F., 2008. Genetic races associated with the genera and sections of host species in the holoparasitic plant Cytinus (Cytinaceae) in the Western Mediterranean basin. New Phytol. 178, 875-887. de Vega, C., Arista, M., Ortiz, P.L., Herrera, C.M., Talavera, S., 2009. The ant-pollination system of Cytinus hypocistis (Cytinaceae), a Mediterranean root holoparasite. Ann. Bot. 103, 1065-1075.

de Vega, C., Arista, M., Ortiz, P.L., Talavera, S., 2010. Anatomical relations among endophytic holoparasitic angiosperms, autotrophic host plants and mycorrhizal fungi, a novel tripartite interaction. Am. J. Bot. 97, 730-737.

de Vega, C., Herrera, C.M., 2012. Relationships among nectar-dwelling yeasts, flowers and ants: patterns and incidence on nectar traits. Oikos 121, 1878-1888.

de Vega, C., Herrera, C.M., 2013. Microorganisms transported by ants induce changes in floral nectar composition of an ant-pollinated plant. Am. J. Bot. 100, 792-800. 
Dobson, H.E.M., 2006. Relationship between floral fragrance and type of pollinator. In, Dudareva, N., Pichersky, E. (Eds.) Biology of Floral Scent. CRC Press; Boca Raton, pp. 147-198.

Dötterl, S., Wolfe, L.W., Jürgens, A., 2005a. Qualitative and quantitative analyses of flower scent in Silene latifolia. Phytochemistry 66, 203-213.

Dötterl, S., Füssel, U., Jürgens, A., Aas, G., 2005b. 1,4-Dimethoxybenzene, a floral scent compound in willows that attracts an oligolectic bee. J. Chem. Ecol. 31, 2993-2998.

Dötterl, S., Jürgens, A., Seifert, K., Laube, T., Weissbecker, B., Schutz, S., 2006. Nursery pollination by a moth in Silene latifolia: the role of odours in eliciting antennal and behavioural responses. New Phytol. 169, 707-718.

Dutton, E.M., Frederickson, M.E., 2012. Why ant pollination is rare: new evidence and implications of the antibiotic hypothesis. Arthropod Plant Interact. 6, 561-569.

Edwards, D.P., Hassall, M., Sutherland, W.J., Yu, D.W., 2006. Assembling a mutualism: ant symbionts locate their host plants by detecting volatile chemicals. Ins. Soc. 53, 172176.

Farré-Armengol, G., Filella, I., Llusia, J., Peñuelas, J., 2013. Floral volatile organic compounds, between attraction and deterrence of visitors under global change. Perspect. Plant Ecol. Evol. Syst. 15, 56-67.

Fenster, C.B., Armbruster, W.S., Wilson, P., Dudash, M.R., Thomson, J.D., 2004. Pollination syndromes and floral specialization. Annu. Rev. Ecol. Syst. 35, 375-403.

Fernández, I., Martín-Cacao, M., Ortiz, P.L., 1992. Contribución al conocimiento melitopalinilógico de Sierra Morena. Lazaroa 13, 41-48.

Galen, C., 1983. The effects of nectar thieving ants on seed set in floral scent morphs of Polemonius viscosum. Oikos 41, 245-249. 
García-Franco, J.G., Rico-Gray, V., 1997. Reproductive biology of the holoparasitic endophyte Bdallophyton bambusarum (Rafflesiaceae). Bot. J. Linn. Soc. 123, 237-247. Gómez, J.M., Zamora, R., 1992. Pollination by ants: Consequences of the quantitative effects on a mutualistic system. Oecologia 91, 410-418.

5 Guerrant, E.O., Fiedler P.L., 1981. Flower defenses against nectar-pilferage by ants. Biotropica 13, 25-33.

Heil, M., Orona-Tamayo, D., Eilmus, S., Kautz, S., Gonzalez-Teuber, M., 2010. Chemical communication and coevolution in an ant-plant mutualism. Chemoecology 20, 63-74.

Heil, M., McKey, D., 2003. Protective ant-plant interactions as model systems in ecological and evolutionary research. Ann. Rev. Ecol. Syst. 34, 425-453.

Hickman, J.C., 1974. Pollination by ants, a low-energy system. Science 184, 1290-1292.

Hölldobler, B., 1999. Multimodal signals in ant communication. J. Comp. Physiol. A 184, $129-141$.

Hull, D.A., Beattie, A.J., 1988. Adverse effects on pollen exposed to Atta texana and other North American ants: implications for ant pollination. Oecologia 75, 153-155.

Ibanez, S., Dötterl, S., Anstett, M., Baudino, S., Caissard, J., Gallet, C., Després, L., 2010. The role of volatile organic compounds, morphology and pigments of globeflowers in the attraction of their specific pollinating flies. New Phytol. 188, 451-463.

Inui, Y., Itioka, T., 2007. Species-specific leaf volatile compounds of obligate Macaranga myrmecophytes and host-specific aggressiveness of symbiotic Crematogaster ants. J. Chem. Ecol. 33, 2054-2063.

Irwin, M.T., Jean-Luc Raharison, F., Rakotoarimanana, H., Razanadrakoto, E., Ranaivoson, E., Rakotofanala, J., Randrianarimanana, C., 2007. Diademed sifakas (Propithecus diadema) use olfaction to forage for the inflorescences of subterranean parasitic plants 
(Balanophoraceae, Langsdorffia sp., and Cytinaceae, Cytinus sp.). Am. J. Primatol. 69, 471-476.

Johnson, S.D., Burgoyne, P., Harder, L., Dötterl, S., 2011. Mammal pollinators lured by the scent of a parasitic plant. Proc. Roy. Soc. B 278, 2303-2310.

5 Junker, R.R., Blüthgen, N., 2008. Floral scents repel potentially nectar thieving ants. Evol. Ecol. Res. 10, 295-308.

Junker, R.R., Chung, A.Y.C., Blüthgen, N., 2007. Interactions between flowers, ants and pollinators: additional evidence for floral repellence against ants. Ecol. Res. 22, 665670.

Junker, R.R., Daehler, C., Dötterl, S., Keller, A., Blüthgen, N., 2011a. Ant-flower networks in Hawai'i: nectar-thieving ants prefer undefended native over introduced plants with floral defenses. Ecol. Monogr. 81, 295-311.

Junker, R.R., Gershenzon, J., Unsicker, S.B., 2011b. Floral odor bouquet loses its ant repellent properties after inhibition of terpene biosynthesis. J. Chem. Ecol. 37, 13231331.

Kaiser, R., 2006. Meaningful scents around the world: olfactory, chemical, biological, and cultural considerations. Wiley-VCH, Zurich, Switzerland.

Knudsen, J.T., Eriksson, R., Gershenzon, J., Stahl, B., 2006. Diversity and distribution of floral scent. Bot. Rev. 72, 1-120.

Lenoir, A., D’Ettorre, P., Errard, C., Hefetz, A., 2001. Chemical ecology and social parasitism in ants. Annu. Rev. Entomol. 46, 573-599.

Lucas, C., Pho, D.B., Jallon, J.M. and Fresneau, D., 2005. Role of cuticular hydrocarbons in the chemical recognition between ant species in the Pachycondyla villosa species complex. J. Insect Physiol. 51, 1148-1157.

Mabberley, D., 1997. The plant book, 2nd edn. Cambridge University Press. Cambridge. 
Maia, A.C.D., Dötterl, S., Kaiser, R., Silberbauer-Gottsberger, I., Teichert, H., Gibernau, M., Navarro, D.M.A.F., Schlindwein, C., Gottsberger, G., 2012. The key role of 4-methyl5-vinylthiazole in the attraction of scarab beetle pollinators: a unique olfactory floral signal shared by Annonaceae and Araceae. J. Chem. Ecol. 38, 1072-1080.

Martin, S.J., Drijfhout, F.P., 2009. A review of ant cuticular hydrocarbons. J. Chem. Ecol. 35, $1151-1161$.

Martin, S.J., Vitikainen, E., Helanterä, H., Drijfhout, F.P., 2008. Chemical basis of nest-mate discrimination in the ant Formica exsecta. Proc. Roy. Soc. Lon. B. 275, 1271-1278.

Metcalf, R.L., Lampman, R.L., Deemdickson, L., 1995. Indole as an olfactory synergist for volatile kairomones for diabroticite beetles. J. Chem. Ecol. 21, 1149-1162.

Metcalf, R.L, Lampman, R.L.,1989. Cinnamyl alcohol and analogs as attractants for corn rootworms (Coleoptera, Chrysomelidae). J. Econ. Entomol. 82, 1620-1625.

Ness, J.H., Bronstein, J.L., Andersen, A.N., Holland J.N., 2004. Ant body size predicts dispersal distance of ant-adapted seeds: Implications of small ant invasions. Ecology $85,1244-1250$.

Ness, J.H., 2006. A mutualism’s indirect costs: the most aggressive plant bodyguards also deter pollinators. Oikos 113, 506-514.

Peakall, R., Beattie, A.J., James, H., 1987. Pseudocopulation of an orchid by male ants: a test of two hypotheses accounting for the rarity of ant pollination. Oecologia 73, 522-524.

Peakall, R., Beattie, A.J., 1989. Pollination of the orchid Microtis parviflora R. Br. by flightless worker ants. Funct. Ecol. 3, 515-522.

Peakall, R., Beattie, A. J., 1991. The genetic consequences of worker ant pollination in a selfcompatible clonal orchid. Evolution 45, 1837-1848. 
Peakall, R., Handel, S.N. Beattie, A.J., 1991. The evidence for, and importance of ant pollination. In Huxley, C.R., Cutler, D.F. (Eds.) Ant-Plant Interactions. Oxford Univ. Press; Oxford, pp. 421-429.

Peakall, R., 1994. Interactions between orchids and ants. In Arditti, J. (Ed.) Orchid Biology Reviews and Perspectives vol VI. John Wiley; New York, pp. 103-133.

Peakall, R., Ebert, D., Poldy, J., Barrow, R.A., Francke, W., Bower, C.C., Schiestl, F.P., 2010. Pollinator specificity, floral odour chemistry and the phylogeny of Australian sexually deceptive Chiloglottis orchids, implications for pollinator-driven speciation. New Phytol. 188, 437-450.

Philpott, S.M., Greenberg, R., Bichier, P., 2005. The influence of ants on the foraging behavior of birds in an agroforest. Biotropica 37, 468-471.

Raguso, R.A., 2001. Floral scent, olfaction, and scent driven foraging behavior. In, Chittka, L., Thomson, J.D. (Eds.) Cognitive ecology of pollination; Animal behavior and floral evolution. Cambridge University Press; Cambridge, pp. 83-105.

Raguso, R.A., 2008. Wake up and smell the roses, the ecology and evolution of floral scent. Annu. Rev. Ecol. Evol. Syst. 39, 549-569.

Ramsey, M., 1995. Ant pollination of the perennial herb Blandfordia grandiflora (Liliaceae). Oikos 74, 265-272.

Rico-Gray ,V., Oliveira, P.S., 2007. The ecology and evolution of ant-plant interactions. The University of Chicago Press, Chicago.

Schäffler, I., Balao, F., Dötterl, S., 2012. Floral and vegetative cues in oil-secreting and nonoil-secreting Lysimachia species. Ann. Bot. 110, 125-138.

Schiestl, F.P., 2010. The evolution of floral scent and insect chemical communication. Ecol. Lett. 13, 643-656. 
Schiestl, F.P., Dötterl, S. 2012. The evolution of floral scent and olfactory preferences in pollinators: coevolution or pre-existing bias? Evolution 66, 2042-2055.

Schiestl, F.P, Glaser, F., 2012. Specific ant-pollination in an alpine orchid and the role of floral scent in attracting pollinating ants. Alp. Bot. 122, 1-9.

5 Schulz, S., Francke, W., Edgar, J., 1988. Volatile compounds from androconial organs of danaine and ithomiine butterflies. Z. Naturforsch. C. 43, 99-104.

Schürch, S., Pfunder, M., Roy, B.A., 2000. Effects of ants on the reproductive success of Euphorbia cyparissias and associated pathogenic rust fungi. Oikos 88, 6-12.

Steenhuisen S.L., Jürgens, A., Johnson, S.D., 2013. Effects of volatile compounds emitted by Protea species (Proteaceae) on antennal electrophysiological responses and attraction of cetoniine beetles. J. Chem. Ecol. 39, 438-446.

Sugiura, N., Miyazaki, S., Nagaishi, S., 2006. A supplementary contribution of ants in the pollination of an orchid, Epipactis thunbergii, usually pollinated by hover flies. Pl. Syst. Evol. 258, 17-26.

Valterová, I., Kunze, J., Gumbert, A., Luxová, A., Liblikas, I., Kalinová, B., Borg-Karlson, A.K., 2007. Male bumble bee pheromonal components in the scent of deceit pollinated orchids; unrecognized pollinator cues? Arthropod Plant Interact. 1, 137-145.

van Wilgenburg, E., Symonds, M.R., Elgar, M.A., 2011. Evolution of cuticular hydrocarbon diversity in ants. J. Evol. Biol. 24, 1188-1198.

Verheggen, F.J., Arnaud, L., Bartram, S., Gohy, M., Haubruge, E., 2008. Aphid and plant secondary metabolites induce oviposition in an aphidophagous hoverfly. J. Chem. Ecol. 34, 301-307.

Visser, J., 1981. South African parasitic flowering plants. Juta \& Co, Capetown.

Willmer, P.G., Stone, G.N., 1997. How aggressive ant-guards assist seed-set in Acacia flowers. Nature 388, 165-167. 
Willmer, P.G., Nuttman, C.V., Raine, N.R., Stone, G.N., Pattrick, J.G., Henson, K. Stillman, P., McIlroy, L., Potts, S.G., Knudsen, J.T., 2009. Floral volatiles controlling ant behaviour. Funct. Ecol. 23, 888-900.

Yang, Y., Battesti, M.J., Djabou, N., Muselli, A., Paolini, J., Tomi, P., Costa, J., 2012. Melissopalynological origin determination and volatile composition analysis of Corsican “chestnut grove” honeys. Food Chem. 132, 2144-2154.

Youngsteadt, E., Nojima, S., Häberlein, C., Schulz, S., Schal, C., 2008. Seed odor mediates an obligate ant-plant mutualism in Amazonian rainforests. Proc. Natl. Acad. Sci. U.S.A. 105, 4571-4575. 
Figure legends

Figure 1. Inflorescences of Cytinus and ants involved in pollination and experimental trials. (A) Inflorescences of yellow-flowered and (B) pinkish-flowered Cytinus. (C) Crematogaster auberti visiting a male flower. (D) Two Aphaenogaster senilis attracted to a wick containing a blend of synthetic (E)-cinnamyl alcohol, $(E)$-cinnamaldehyde, and 4-oxoisophorone.

Figure 2. Non-metric multidimensional scaling of flower scent samples collected in different Cytinus races and populations. The names and structures of most abundant compounds are also plotted. CP, pink-flowered populations. CY, yellow-flowered populations. $\mathrm{d}=$ day, $\mathrm{n}=$ night.

Figure 3. Coupled gas chromatographic-electroantennographic detection (GC-EAD) using an antenna of Aphaenogaster senilis and testing a scent sample containing 4oxoisophorone, $(E)$-cinnamaldehyde, and (E)-cinnamyl alcohol.

Figure 4. Mean number of visits throughout the day (A) and total number of visits of different species of ants (B) attracted by Cytinus inflorescence olfactory cues (black circles and black bars; hidden inflorescences) and negative controls (white circles and white bars; empty holes). In (A) circles represent mean values and vertical bars represent the standard error. In (B), star symbols indicate statistically significant differences: **, $P=0.001 ; * * *, P<0.0001$; n.s. $=$ nonsignificant differences $(P>0.05)$. Figure 5. Proportion of wicks visited by ants in each census in the two-choice trials involving the most abundant compounds in the scent of Cytinus flowers: $(E)$ cinnamaldehyde, (E)-cinnamyl alcohol, 4-oxoisophorone and the synthetic blend of these three compounds. Means are presented along with their 95\%CI values. Different letters above bars indicate significant differences according to post hoc tests. 
Figure 1S. Supplementary material. Number of visits throughout the day of different ant species to hidden inflorescence of Cytinus (black circles) and controls (white circles; empty holes). Circles represent mean values. Note that for each species the y-axis differs.

Figure 2S. Supplementary material. Total number of ant visits in the two-choice trials involving the most abundant volatile compounds in the scent of Cytinus flowers: $(E)$ cinnamaldehyde, (E)-cinnamyl alcohol, 4-oxoisophorone and the synthetic blend of these three compounds. Symbols indicate significant differences: *** $P<0.0001$, n.s. nonsignificant differences $(P>0.05)$. 
Appendix 1. Plant species pollinated by ants and ant species involved. The studies are chronologically ordered and grouped by decades.

\begin{tabular}{|c|c|c|c|c|c|}
\hline Plant species & Plant family & Life habit & Flower colour & Ant pollinator & Reference \\
\hline \multicolumn{6}{|l|}{ 1970s } \\
\hline Polygonum cascadense & Polygonaceae & Annual herb & White & Formica argentea & Hickman, 1974 \\
\hline Microtis parviflora & Orchidaceae & Herb & Green & $\begin{array}{l}\text { Iridomyrmex sp., Meranoplus sp., and } \\
\text { Rhytidoponera tasmaniensis }\end{array}$ & Jones, 1975 \\
\hline Epipactis palustris & Orchidaceae & Herb & Greenish-purple & $\begin{array}{l}\text { Lasius niger, Formica fusca, and } F \text {. } \\
\text { rufibarbis }\end{array}$ & Nilsson, 1978 \\
\hline \multicolumn{6}{|l|}{ 1980s } \\
\hline Epipactis palustris & Orchidaceae & Herb & Greenish-purple & Lasius niger and Formica polyctena & Brantjes, 1981 \\
\hline Diamorpha smallii & Crassulaceae & Annual herb & White & Formica schaufussi and F. subsericea & $\begin{array}{l}\text { Wyatt and } \\
\text { Stoneburner, } 1981\end{array}$ \\
\hline Mangifera indica L. & Anacardiaceae & Tree & White & Iridomyrmex sp. (purpureus group) & $\begin{array}{l}\text { Anderson et al., } \\
1982\end{array}$ \\
\hline Scleranthus perennis & Caryophyllaceae & Perennial herb & Green & Formica rufibarbis & $\begin{array}{l}\text { Svensson, 1985, } \\
1986\end{array}$ \\
\hline Leporella fimbriata & Orchidaceae & Herb & Green & Myrmecia urens & $\begin{array}{l}\text { Peakall, 1989; } \\
\text { Peakall et al., } \\
\text { 1987, } 1990\end{array}$ \\
\hline Microtis parviflora & Orchidaceae & Herb & Green & $\begin{array}{l}\text { Iridomyrmex gracilis, Monomorium } \\
\text { sp., Crematogoster sp., and } \\
\text { Polyrochis spp. }\end{array}$ & $\begin{array}{l}\text { Peakall and } \\
\text { Beattie, } 1989\end{array}$ \\
\hline
\end{tabular}

1990s 


\begin{tabular}{|c|c|c|c|c|c|}
\hline Hormathophylla spinosa & Cruciferae & Shrub & White & Proformica longiseta & $\begin{array}{l}\text { Gómez and } \\
\text { Zamora, } 1992\end{array}$ \\
\hline Petrosavia sakuraii & Petrosaviaceae & Saprophytic herb & Light-brown & $\begin{array}{l}\text { Paratrechina flavipes, Camponotus } \\
\text { obscuripes, and C. tokioensis }\end{array}$ & $\begin{array}{l}\text { Takahashi et al } \\
1993\end{array}$ \\
\hline Borderea pyrenaica & Dioscoreaceae & Geophyte & Green & Leptothorax tuberum & García et al., 1 \\
\hline Blanfordia grandiflora & Liliaceae & Herb & Red & Iridomyrmex sp. & Ramsey, 1995 \\
\hline Alyssum purpureum & Cruciferae & Dwarf shrub & Pink & Proformica longiseta & Gómez et al., 1 \\
\hline Arenaria tetraquetra & Caryophyllaceae & Cushoin plant & White & $\begin{array}{l}\text { Proformica longiseta and Tapinoma } \\
\text { nigerrimum }\end{array}$ & Gómez et al., 1 \\
\hline Frankenia thymifolia & Frankeniaceae & Dwarf shrub & Pink & $\begin{array}{l}\text { Camponotus foreli, Camponotus sp., } \\
\text { and Leptothorax fuentei }\end{array}$ & Gómez et al., \\
\hline Retama sphaerocarpa & Fabaceae & Treelet & Yellow & Camponotus foreli & Gómez et al., 1 \\
\hline Sedum anglicum & Crassulaceae & Perennial herb & White & Proformica longiseta & Gómez et al., 1 \\
\hline Paronychia pulvinata & Caryophyllaceae & Cushoin plant & Green & Formica neorufibarbis & Puterbaugh, 19 \\
\hline \multicolumn{6}{|c|}{$000 \mathrm{~s}$} \\
\hline Lobularia maritima & Cruciferae & Perennial herb & White & Camponotus micans & Gómez, 2000 \\
\hline Euphorbia cyparissias & Euphorbiaceae & Perennial herb & Green & $\begin{array}{l}\text { Lasius alienus, Formica pratensis, } \\
\text { and F. cunicularia }\end{array}$ & $\begin{array}{l}\text { Schürch et al., } \\
2000\end{array}$ \\
\hline Balanophora kuroiwai & Balanophoraceae & Parasitic herb & No perianth & Leptothorax sp. & $\begin{array}{l}\text { Kawakita and } \\
\text { Kato, } 2002\end{array}$ \\
\hline
\end{tabular}




\begin{tabular}{|c|c|c|c|c|c|}
\hline Balanophora tobiracola & Balanophoraceae & Parasitic herb & No perianth & $\begin{array}{l}\text { Aphaenogaster sp., and Paratrechina } \\
\text { flavipes }\end{array}$ & $\begin{array}{l}\text { Kawakita and } \\
\text { Kato, } 2002\end{array}$ \\
\hline Fragaria virginiana & Rosaceae & Perennial herb & White & $\begin{array}{l}\text { Prenolepis impairs, Formica } \\
\text { subsericea, and Tapinoma sessile }\end{array}$ & $\begin{array}{l}\text { Ashman and King, } \\
2005\end{array}$ \\
\hline Epipactis thunbergii & Orchidaceae & Herb & Yellow & Camponotus japonicus & $\begin{array}{l}\text { Sugiura et al., } \\
2006\end{array}$ \\
\hline Trinia glauca & Apiaceae & Perennial herb & White & $\begin{array}{l}\text { Lasius alienus, Formica fusca, and } \\
\text { Temnothorax albipennis }\end{array}$ & $\begin{array}{l}\text { Carvalheiro et al., } \\
2008\end{array}$ \\
\hline Neottia listeroides & Orchidaceae & Saprophytic herb & Green & Leptothoras sp. and Paratrechina sp. & Wang et al., 2008 \\
\hline Chenorchis singchii & Orchidaceae & Epiphytic herb & Purple & Temnothorax sp. & $\begin{array}{l}\text { Zhongjian et al., } \\
2008\end{array}$ \\
\hline Cytinus hypocistis & Cytinaceae & Parasitic herb & Yellow & $\begin{array}{l}\text { Aphaenogaster senilis, Camponotus } \\
\text { pilicornis, Crematogaster auberti, C. } \\
\text { scutellaris, Pheidole pallidula, } \\
\text { Plagiolepis pygmaea, P. schmitzii, } \\
\text { Tapinoma nigerrimum, Tetramorium } \\
\text { ruginode, and T. semilaeve }\end{array}$ & $\begin{array}{l}\text { de Vega et al., } \\
2009\end{array}$ \\
\hline Phyllanthus lepidocarpus & Phyllanthaceae & Annual herb & White & Formica japonica and Formica sp. & $\begin{array}{l}\text { Kawakita and } \\
\text { Kato, } 2009\end{array}$ \\
\hline Euphorbia geniculata & Euphorbiaceae & Annual herb & Green & Camponotus compressus & Araf et al., 2010 \\
\hline Euphorbia seguieriana & Euphorbiaceae & Perennial herb & Green & ? & $\begin{array}{l}\text { Rostás and Taútz, } \\
2011\end{array}$ \\
\hline Naufraga balearica & Umbelliferae & $\begin{array}{l}\text { Caespitose } \\
\text { chamaephyte }\end{array}$ & Pinkish white & $\begin{array}{l}\text { Plagiolepis pygmaea, Lasius grandis, } \\
\text { Pheidole pallidula, Temnothorax } \\
\text { recedens, and Camponotus ruber }\end{array}$ & $\begin{array}{l}\text { Cursach and Rita, } \\
\text { 2012a }\end{array}$ \\
\hline
\end{tabular}




\begin{tabular}{|c|c|c|c|c|c|}
\hline Apium bermejoi & Umbelliferae & $\begin{array}{l}\text { Hemicryptophyte } \\
\text { stoloniferous }\end{array}$ & Pinkish white & $\begin{array}{l}\text { Pheidole pallidula, Tapinoma } \\
\text { madeirense, Lasius grandis, and } \\
\text { Plagiolepis pygmaea }\end{array}$ & $\begin{array}{l}\text { Cursach and Rita, } \\
\text { 2012b }\end{array}$ \\
\hline Borderea chouardii & Dioscoreaceae & Geophyte & Green & Lasius grandis and L. cinereus & García et al., 2012 \\
\hline Chamorchis alpina & Orchidaceae & Herb & Green & $\begin{array}{l}\text { Formica lemani and Leptothorax } \\
\text { acervorum }\end{array}$ & $\begin{array}{l}\text { Schiestl and } \\
\text { Glaser, } 2012\end{array}$ \\
\hline Epifagus virginiana & Orobanchaceae & Parasitic herb & Purple & $\begin{array}{l}\text { Crematogaster spp., and Prenolepis } \\
\text { imparis }\end{array}$ & $\begin{array}{l}\text { Abbate and } \\
\text { Campbell, } 2013\end{array}$ \\
\hline
\end{tabular}

\section{REFERENCES}

Abbate, A.P., Campbell, J.W., 2013. Parasitic beechdrops (Epifagus virginiana): a possible ant- pollinated plant. Southeast. Nat. 12, 661-665.

Anderson, D.L., Sedgley, M., Short, J.R.T., Allwood, A.J., 1982. Insect pollination of mango in northern Australia Mangifera indica. Aust. J.

Agr. Res. 33, 541-548. 
Araf, M., Kumar, S., Hamal, I.A., 2010. Ant pollination of an invasive non-native weed, Euphorbia geniculata Ortega in north west Himalaya (India). The Bioscan 5, 81-83.

Ashman, T.L., King, E.A., 2005. Are flower-visiting ants mutualists or antagonists? A study in a gynodioecious wild strawberry. Am. J. Bot. 92, 891-895.

Brantjes, N.B.M., 1981. Ant, bee and fly pollination in Epipactis palustris (L) Crantz (Orchidiaceae). Acta Bot. Neerl. 30:59-68.

Carvalheiro, L.G., Barbosa, E.R.M., Memmott, J., 2008. Pollinator networks, alien species and the conservation of rare plants: Trinia glauca as a case study. J. Appl. Ecol. 45, 1419-1427.

Cursach, J., Rita, J., 2012a. Implications of the reproductive biology of the narrow endemic Naufraga balearica (Apiaceae) for its conservation status. Plant Syst. Evol. 298, 581-596.

Cursach, J., Rita, J., 2012b. Reproductive biology and reproductive output assessment in natural and introduced subpopulations of Apium bermejoi, a ‘Critically Endangered’ endemic plant from Menorca (western Mediterranean). Nord. J. Bot. 30, 754-768.

de Vega, C., Arista, M., Ortiz, P.L., Herrera, C.M., Talavera, S., 2009. The ant-pollination system of Cytinus hypocistis (Cytinaceae), a Mediterranean root holoparasite. Ann. Bot. 103, 1065-1075.

García, M.B., Antor, R.J., Espadaler, X., 1995. Ant pollination of the palaeoendemic dioecious Borderea pyrenaica (Dioscoreaceae). Plant Syst. Evol. 198, 17-27. 
García, M.B., Espadaler, X., Olesen, J.M., 2012. Extreme reproduction and survival of a true cliffhanger: the endangered plant Borderea chouardii (Dioscoreaceae). PLoS ONE 7(9): e44657.

Gómez, J.M., 2000. Effectiveness of ants as pollinators of Lobularia maritima: Effects on main sequential fitness components of the host plant. Oecologia 122, 90-97.

Gómez, J.M., Zamora, R., 1992. Pollination by ants: Consequences of the quantitative effects on a mutualistic system. Oecologia 91, 410-418.

Gómez, J.M., Zamora, R., Hódar, J.A., García, D., 1996. Experimental study of pollination by ants in Mediterranean high mountain and arid habitats. Oecologia 105, 236-242.

Hickman, J.C., 1974. Pollination by ants, a low-energy system. Science 184, 1290-1292.

Jones, D.L., 1975. Pollination of Microtis parviflora R.Br. Ann. Bot. 39, 585-589.

Kawakita, A., Kato, M., 2002. Floral biology and unique pollination system of root holoparasites, Balanophora kuroiwai and B. tobiracola (Balanophoraceae). Am. J. Bot. 89, 1164-1170.

Kawakita, A., Kato, M., 2009. Repeated independent evolution of obligate pollination mutualism in the Phyllantheae-Epicephala association. Proc. R. Soc. Lond. B Biol. Sci. 276, 417-426.

Luo, C.W., Li, K., Chen, X.M., Huang, Z.Y., 2012. Ants contribute significantly to the pollination of a biodiesel plant, Jatropha curcas. Environ. Entomol. 41, 1163-1168. 
Nilsson, L.A., 1978. Pollination ecology of Epipactis palustris (Orchidaceae). Bot. Notiser 131, 355-368.

Peakall, R., 1989. The unique pollination of Leporella fimbriata (Orchidaceae): Pollination by pseudocopulating male ants (Myrmecia urens, Formicidae). Plant Syst. Evol. 167, 137-148.

Peakall, R., Beattie, A.J., 1989. Pollination of the orchid Microtis parviflora R. Br. by flightless worker ants. Funct. Ecol. 3, 515-522.

Peakall, R., Beattie, A.J., James, H., 1987. Pseudocopulation of an orchid by male ants: a test of two hypotheses accounting for the rarity of ant pollination. Oecologia 73, 522-524.

Peakall, R., Angus, C.J., Beattie, A., 1990. The significance of ant and plant traits for ant pollination in Leporella fimbriata. Oecologia 84, 457460.

Puterbaugh, M.N., 1998. The roles of ants as flower visitors: Experimental analysis in three alpine plant species. Oikos 83, 36-46.

Ramsey, M., 1995. Ant pollination of the perennial herb Blandfordia grandiflora (Liliaceae). Oikos 74, 265-272.

Rostás, M., Tautz, J., 2011. Ants as pollinators of plants and the role of floral scents. In, Dubinsky, Z., Seckbach, J. (Eds.), All flesh is grass. Springer; Berlin, pp. 151-161.

Schiestl, F.P, Glaser, F., 2012. Specific ant-pollination in an alpine orchid and the role of floral scent in attracting pollinating ants. Alp. Bot. 122, 1-9. 
Schürch, S., Pfunder, M., Roy, B.A., 2000. Effects of ants on the reproductive success of Euphorbia cyparissias and associated pathogenic rust fungus. Oikos 88, 6-12.

Sugiura, N., Miyazaki, S., Nagaishi, S., 2006. A supplementary contribution of ants in the pollination of an orchid, Epipactis thunbergii, usually pollinated by hover flies. Pl. Syst. Evol. 258, 17-26.

Svensson, K., 1985. An estimate of pollen carryover by ants in a natural population of Scleranthus perennis L. (Caryophyllaceae). Oecologia 56, 373-377.

Svensson, K., 1986. Secondary pollen carryover by ants in a natural population of Scleranthus perennis (Caryophyllaceae). Oecologia 70, 631632.

Takahashi, H., Nishio, E., Hayashi, H., 1993. Pollination biology of the saprophytic species Petrosavia sakurafi (Makino) van Steenis in Central Japan. J. Plant Res. 106, 213-217.

Wang, C.Q., Luo, Y.B., Tai, Y.D., An, D.J., Kou Y., 2008. Ants pollinate Neottia listeroides (Orchidaceae) in Sichuan, China. J. Syst. Evol. 46, 836-846.

Wyatt, R., Stoneburner, A., 1981. Patterns of ant-mediated pollen dispersal in Diamorpha smallii (Crassulaceae). Syst. Bot. 6, 1-7.

Zhongjian, L., Lijun, C., Kewei, L., Liqiang, L., Xueyong, M., Wenhui, R., 2008. Chenorchis, a new orchid genus, and its eco-strategy of ant pollination. Acta Ecol. Sin. 28, 2433-2444. 